\title{
IbM TAHU BAKSO "ASUH" DI KECAMATAN BOYOLALI KABUPATEN BOYOLALI
}

\author{
Edhi Nurhartadi, R. Baskara A, Bara Yudhistira \\ Fakultas Pertanian Universitas Sebelas Maret \\ email: barayudhistira@yahoo.co.id
}

\begin{abstract}
Tofu meatballs is a snack that is made from tofu as the mayor ingredients with meat dough stuffing through the process of steaming and frying. Tofu meatballs become one of food innovation from tofu which serve delicious taste. EQ company in Karanggeneng Village, Boyolali District has a production capacity of 700-800 tofu meatballs on Monday-Saturday and 400 tofu meatballs on holiday. The problems faced by the home-processing in home industry know meatballs are among others related to the quality of tofu meatballs that have not met the expectations of buyers. Another obstacle faced is the stagnant business conditions due to the lack of product diversification, the equipment used is still limited and simple, the production capacity is minimal, the packing of tofu meatballs produced is also less attractive. Program implemented (1) Introduction of production process know meatballs technology that meets quality management of processed foods ASUH (safe, healthy, whole and halal); (2) Introduction of appropriate technology for the processing of tofu meatballs in the form of refrigerator machinery and other means of production improvement; (3) Introduction of technological variations of packaging materials such as hand sealer machine; (4) Management of Food Industry License (PIRT); (5) Simple marketing and bookkeeping training. This has been set forth in the letter of cooperation agreement. The results of dedication activities that have been done by the dedication team are coordinating with partners about problem solving effort, training on how to make meatball tofu with quality management concept "ASUH" that is safe, healthy, whole and halal.
\end{abstract}

Keywords: ASUH, quality, tofu meatballs, production process, management.

\begin{abstract}
ABSTRAK
Tahu bakso merupakan makanan ringan yang umumnya terbuat dari tahu sebagai bahan dasarnya dengan isian adonan daging yang melalui proses pengukusan dan penggorengan. Tahu bakso goreng menjadi salah satu inovasi makanan dari tahu yang menyajikan rasa lezat, enak dan juga sangat gurih. Pengrajin tahu bakso EQ di Desa Karanggeneng, Kecamatan Boyolali ini memiliki kapasitas produksi mencapai 700-800 tahu bakso di
\end{abstract}


hari Senin-Sabtu dan 400 tahu bakso di hari libur. Permasalahan yang dihadapi pengrajin industri rumah tangga pengolahan tahu bakso ini antara lain terkait dengan mutu tahu bakso yang belum memenuhi harapan pembeli. Kendala lain yang dihadapi adalah kondisi usaha yang stagnan karena tidak adanya diversifikasi produk, peralatan yang digunakan masih terbatas dan sederhana, kapasitas produksi minimal, pengemasan tahu bakso yang dihasilkan juga kurang menarik. Program yang dilaksanakan (1) Introduksi teknologi proses produksi tahu bakso yang memenuhi manajemen mutu pangan olahan ASUH (aman, sehat, utuh dan halal); (2) Introduksi teknologi tepat guna proses pengolahan tahu bakso berupa mesin refrigerator dan alat peningkatan produksi lain; (3) Introduksi teknologi variasi bahan pengemas berupa mesin hand sealer; (4) Pengurusan ijin Pangan Industri Rumah Tangga (PIRT) tahu bakso; (5) Pelatihan manajemen pemasaran dan pembukuan sederhana. Hal tersebut telah dituangkan dalam surat perjanjian kerjasama. Hasil kegiatan pengabdian yang telah dilakukan tim pengabdian antara lain melakukan koordinasi dengan mitra tentang upaya penyelesaian masalah yang dihadapi, melakukan pelatihan bagaimana membuat tahu bakso dengan konsep manajemen mutu "ASUH" yaitu aman, sehat, utuh dan halal.

Kata kunci: ASUH, mutu, tahu bakso, proses produksi, manajemen.

\section{PENDAHULUAN}

Kabupaten Boyolali merupakan salah satu kabupaten yang telah banyak mampu mengembangkan industri pengolahan pangan. Data Perindustrian dan Perdagangan Kabupaten Boyolali menunjukkan berbagai industri kecil dan rumah tangga mampu bertahan sampai saat ini. Kecamatan Boyolali merupakan salah satu daerah di kabupaten Boyolali yang memiliki banyak sentra industri rumah tangga. Tercatat terdapat sedikitnya 1109 usaha kecil dan rumah tangga yang bergerak dalam berbagai bidang (Boyolali Dalam Angka, 2015). Salah satu industri rumah tangga yang banyak dilakukan masyarakat di Desa Karanggeneng, Kecamatan
Boyolali adalah pengolahan tahu bakso.

Tahu bakso merupakan makanan ringan yang umumnya terbuat dari tahu sebagai bahan dasarnya dengan tahu dengan isian adonan daging yang melalui proses pengukusan dan penggorengan. Tahu bakso goreng menjadi salah satu inovasi makanan dari tahu yang menyajikan rasa lezt, enak dan juga sangat gurih. Pengrajin tahu bakso di Desa Karanggeneng, Kecamatan Boyolali ini memiliki kapasitas produksi mencapai 700-800 tahu bakso di hari Senin-Sabtu dan 400 tahu bakso di hari libur.

Secara umum masalah yang dihadapi pengrajin industri rumah tangga pengolahan tahu bakso ini 
sama. Kendala utama terkait dengan mutu tahu bakso yang belum memenuhi harapan pembeli. Kendala lain yang dihadapi adalah kondisi usaha yang stagnan karena tidak adanya diversifikasi produk. Usaha ini hanya bertumpu pada satu bahan dasar yaitu tahu dari kacang kedelai dan daging sapi. Harga tahu dan daging sapi yang fluktuatif dan cenderung naik setiap waktu menjadikan pengrajin tahu bakso tidak berani meningkatkan kapasitas produksi. Selain itu, peralatan yang digunakan masih terbatas dan sederhana. Tahu Bakso sendiri merupakan makanan yang proses pengolahannya sederhana hanya membutuhkan proses pengukusan dan penggorengan. Alat yang digunakan umumnya hanya dandang serta wajan secara manual. Proses penggilingan daging untuk isian tahu bakso masih manual ini membutuhkan tenaga lebih, sehingga industri rumah tangga pengolahan tahu bakso ini hanya memiliki kapasitas produksi minimal. Pengemasan tahu bakso yang dihasilkan juga kurang menarik. Pengrajin biasanya hanya mengemas tahu bakso dengan plastik polipropilen biasa tanpa label produk. Permasalahan yang lain adalah belum memilikinya ijin Pangan Industri Rumah Tangga (PIRT). Pengrajin belum dapat menitipkan produknya ke outlet/toko pusat oleh-oleh dikarenakan belum adanya ijin PIRT. Teknik penjualan yang dilakukan juga masih sederhana sehingga tidak berkembangnya daerah pemasaran.

Sebagai upaya untuk menyelesaikan masalah tersebut, tim pengabdian UNS telah bersepakat dengan industri rumah tangga mitra untuk menyelenggarakan program (1) Introduksi teknologi proses produksi tahu bakso yang memenuhi manajemen mutu pangan olahan ASUH (aman, sehat, utuh dan halal); (2) Introduksi teknologi tepat guna proses pengolahan tahu bakso berupa mesin meat grinder, freezer dan alat peningkatan produksi lain; (3) Introduksi teknologi variasi bahan pengemas berupa mesin hand sealer; (4) Pengurusan ijin Pangan Industri Rumah Tangga (PIRT) tahu bakso; (5) Pelatihan manajemen pemasaran dan pembukuan sederhana. Hal tersebut telah dituangkan dalam surat perjanjian kerjasama.

\section{METODE}

Kegiatan pengabdian kepada masyarakat ini menggunakan pendekatan kaji tindak. Dalam kegiatan ini akan diterapkan beberapa metode yang sesuai untuk mencapai tujuan, yakni meningkatkan produktifitas dan efektifitas guna mengembangkan kualitas dan kuantitas produksi karak. Metode tersebut terdiri dari: Solusi yang ditawarkan untuk mengatasi permasalahanpermasalahan yang dihadapi mitra adalah sebagai berikut: 
ISSN : 1979-861X

e-ISSN : 2549-1555

1. Peningkatan kualitas proses produksi dan produk tahu bakso melalui manajemen mutu pangan olahan ASUH

Proses pengolahan tahu bakso terdiri beberapa tahapan yaitu 1) mengkerok bagian tahu yang telah digoreng matang dikerok dibagian tengahnya. Dan ditimbang dengan ukuran kurang lebih yakni 40 g. selanjutnya untuk bahan isian, terdiri bahan isi seperti seledri, tepung sagu, daging giling, putih telur, wortel dengan bahan bumbu yang sudah dihaluskan. Selanjutnya tambahkan bahan sisa kerukan tahu dan diaduk secara merata. Kemudian tahu yang telah dikerok tadi dimasukkan isian adonan tadi ke dalamnya kemudian dikukus di panci selama 15 menit. Jika tahu sudah matang maka dapat diangkat lalu dicelup ke bahan pencelup yang telah dicampurkan dan diaduk rata. Kemudian goreng tahu tersebut dalam minyak yang sudah dipanaskan hingga matang dengan berwarna kecoklatan. Setelah matang diangkat dan tahu bakso goreng dikemas.

Pada tahap ini tim pengabdian akan memberikan pelatihan untuk memproduksi tahu bakso yang memenuhi manajemen mutu pangan olahan ASUH (aman, sehat, utuh dan halal). Tahu bakso yang telah dihasilkan selanjutnya dianalisa kimia untuk mengetahui kandungan gizi yang terdapat pada produk tersebut.

2. Peningkatan efisiensi proses pengolahan tahu bakso melalui introduksi mesin refrigerator dan alat peningkatan produksi lainnya

Proses pembuatan tahu bakso membutuhkan pengukusan dan penggorengan. Proses pengukusan dengan menggunakan dandang dan proses penggorengan menggunakan wajan, memiliki kapasitas produksi yang terbatas. Pengrajin hanya dapat mengolah maksimal $2 \mathrm{~kg}$ tahu bakso, sekali proses pembuatan. Selain itu, pengukusan yang dilakukan kapasitas dandang yang kecil, sehingga produksi tidak dapat maksimal.

3. Introduksi teknologi variasi bahan pengemas

Variasi dalam penggunaan bahan pengemas produk tahu bakso selain berfungsi meningkatkan ketahanan produk dari kerusakan, juga untuk meningkatkan nilai jual produk. Pengemasan yang dilakukan saat ini hanya menggunakan plastik tipis untuk membungkus tahu bakso (pengemas primer), kemudian dimasukkan dalam mika biasa sebagai pengemas sekunder tanpa adanya label produk.

Variasi bahan pengemas yang akan diintroduksikan adalah penggunaan kertas dan plastik 
ISSN : 1979-861X

e-ISSN : 2549-1555

untuk kemasan primer, dan mika, kardus, serta keranjang untuk jenis pengemas sekunder disertai dengan label produk. Bentuk dan design pengemasan yang unik dan menarik ditujukan agar produk tahu bakso memiliki nilai jual yang tinggi serta dapat bersaing dengan produk oleh-oleh yang lain.

4. Pengurusan ijin Pangan Industri Rumah Tangga (PIRT) tahu bakso

Pengurusan ijin Pangan Industri Rumah Tangga (PIRT) sangat diperlukan sebelum memasarkan produk makanan/minuman ke masyarakat. Hal ini diperlukan sebagai izin jaminan usaha makanan/minuman rumahan yang dijual dan beredar di masyarakat memenuhi standar keamanan makanan atau izin edar produk pangan. Belum dimilikinya PIRT pada usaha mitra, mengakibatkan tahu bakso yang dihasilkan oleh industri rumah tangga ini belum dapat dipasarkan ke toko/pusat oleholeh yang berada di wilayah Boyolali. Pemasaran saat ini hanya terbatas pada pesanan masyarakat saja.

Tim pengabdian pada tahap ini akan membantu dan mendampingi pengurusan persyaratan perolehan ijin PIRT pada tahap-tahap berikut ini:

a. Pengurusan surat keterangan domisili usaha dari kecamatan b. Pengurusan surat keterangan dari puskesmas/dokter

c. Denah lokasi dan denah bangunan

d. Surat keterangan usaha dari kelurahan setempat

e. Pembuatan contoh draf label/kemasan

f. Pendaftaran ke Dinkes Boyolali

g. Pendampingan survai, dan

h. Pengecekan berkala sampai ijin PIRT diperoleh

5. Pelatihan manajemen pemasaran dan pembukuan sederhana

Pemasaran merupakan hal yang sangat penting dalam perusahaan. Sebaik apapun kualitas produk yang dihasilkan, jika tidak dapat memasarkan tidak akan berguna bagi perusahaan. Pemasaran sangat menentukan hidup matinya suatu usaha. Pemasaran tahu bakso yang masih terbatas menjadi kendala perkembangan bisnis mitra. Untuk itu akan tim pengabdian berencana memberikan pelatihan manajemen pemasaran yang baik agar usaha tahu bakso dapat berkembang.

Pembukuan merupakan proses pencatatan, pengklasifikasian, dan peringkasan transaksi-transaksi keuangan secara sistematis dan teratur yang disajikan dalam bentuk laporan keuangan, kemudian hasil laporan ini bisa menjadi bahan analisa dan hasilhasilnya diterjemahkan untuk 
menjadi dasar keputusan usaha. Pembukuan sangat penting karena keterbatasan manusia dalam menyimpan data informasi keuangan dari usaha yang dijalankan. Pembukuan berfungsi untuk mengukur sejauh mana perkembangan usaha dan kendala yang dapat diatasi. Pembukuan juga berfungsi untuk menentukan arah ke depan apakah perlu dikembangkan atau dikurangi. Pembukuan juga bisa dijadikan pedoman oleh pihak lain untuk pemberian modal usaha yang akan menunjang perkembangan usaha.

Strategi yang diterapkan untuk menjamin keberhasilan dari berbagai program pada kegiatan ini adalah peralatan yang digunakan sebagai alat pelatihan akan dihibahkan ke pengrajin mitra, sehingga tidak ada kendala lagi bagi para pengrajin. Tim pengabdian juga akan terus melakukan pendampingan sejak produksi, pengurusan perijinan produksi P-IRT hingga pemasaran, untuk menjamin stabilitas dan kontinuitas usaha tahu bakso di UKM 'EQ”.

\section{HASIL DAN PEMBAHASAN}

A.Koordinasi dengan Mitra dan Persiapan Pelaksanaan Kegiatan

Sosialisasi kegiatan pengabdian ini telah dilakukan sejak pengumuman dari LPPM UNS tentang kegiatan hibah IPMIbM PNBP UNS yang lolos didanai pada tahun 2016 kepada mitra. Kegiatan tersebut bertujuan untuk memberikan informasi bahwa dengan kegiatan ini akan melakukan pelatihan yaitu untuk peningkatan kualitas proses produksi dan produk tahu bakso melalui manajemen mutu pangan olahan ASUH (aman, sehat, utuh dan halal), selain itu juga diharapkan sejalan dengan penerapan manajemen tersebut dapat pula meningkatan efisiensi proses pengolahan tahu bakso melalui introduksi alat. Dengan introduksi alat yang sesuai dengan kebutuhan maka hasil produksi akan lebih bagus, baik dari segi kualitas maupun kuantitas.

Dari segi administrasi dan legalitas usaha Tim Pengabdian berusaha melaksanakan harus tersebut yaitu dengan pengurusan ijin Pangan Industri Rumah Tangga (PIRT), sehingga dengan pemenuhan ijin PIRT ini kepercayaan konsumen terhadap produk mitra akan semakin meningkat. Dengan kegiatan ini diharapkan tim pengabdi dapat melakukan transfer teknologi dan informasi sebagai wujud kegiatan Tri Dharma Perguruan tinggi dan Mitra memperoleh ketrampilan diversifikasi dan fasilitas produksi sehingga kegiatan ini dapat berpotensi untuk meningkatkan kesejahteraan UKM mitra maupun seluruh pihak yang terlibat dalam usaha tersebut. 
ISSN : 1979-861X

e-ISSN : 2549-1555

B. Pelaksanaan kegiatan pelatihan peningkatan kualitas proses produksi dan produk tahu bakso melalui manajemen mutu pangan olahan ASUH (aman, sehat, utuh dan halal)

Proses produksi tahu bakso di UKM mitra saat ini masih dilakukan secara manual dan masih menyatu dengan kegiatan dari keluarga mitra. Hal tersebut dapat dilihat dari penggunaan alat bersama antara kegiatan produksi tahu baso dengan kegiatan masak memasak keluarga. Disisi lain proses produksi tahu baso saat ini sebelum dan sesudah produksi, bahan-bahan maupun produk jadi masih disimpan pada tempat terbuka dan sederhana. Hal ini tentunya berpotensi untuk menyebabkan potensi kontaminasi pada produk. Dimana kontaminasi tersebut dapat menyebabkan kerusakan produk atau terjadi penurunan masa simpan produk yang dihasilkan.

Kegiatan pelatihan diberikan langsung kepada pemilik UKM, dengan harapan pemilik tersebut akan secara langsung menularkannya kepada karyawannya. Selain itu juga kegiatan pelatihan berlangsung pada saat proses produksi sehingga pemilik UKM akan langsung dapat mempraktekannya saat itu juga.
Setelah dilakukan pelatihan secara teoritis maupuan praktek langsung, tentunya hal tersebut perlu didukung dengan adanya pemenuhan alat yang sesuai dengan kebutuhan. Hal ini perlu pengadaan alat seperti lemari es. Pengadaan lemari es bertujuan agar tahu bakso yang telah diproduksi sebelum dikirim atau dipasarkan akan disimpan dahulu dalam lemari es.

Penyimpanan tersebut diharapkan akan melindungi tahu baso dari kontaminasi, baik kontaminasi fisik, kimia maupun mikrobiologi. Mengingat dapur sebagai tempat produksi masih kurang besih dalam lantai produksi. Koontaminasi tersebut dapat berupa serangga, debu maupun kontaminasi yang lainnya.

Penggunaan lemari es atau dengan menggunakan suhu dingin akan lebih memaksimalkan umur simpan karena pada suhu dingin akan menghambat pertumbuhan mikroorganisme. Sehingga tahu tidak akan mudah cepat berlendir atau basi.

Kegiatan selanjutnya yaitu pemantauan secara rutin atau berkala terhadap manajemen yang sudah dilatihkan untuk menjaga konsistensi pelaksanaan usaha. Hal tersebut dilakukan karena biasanya UKM pada level grass root, hanya melaksanakan materi pelatihan hanya beberapa waktu saja. Pemantauan tersebut 
ISSN : :1979-861X

e-ISSN : 2549-1555

dilakukan baik secara langsung maupun dengan alat komunikasi.

Introduksi mesin refrigerator dan alat peningkatan produksi lainnya, peningkatan teknologi proses pengemasan tahu bakso yang dihasilkan, pengurusan ijin Pangan Industri Rumah Tangga (PIRT), dan diberikan pelatihan pemasaran tahu bakso dan pembukuan sederhana produk tahu bakso yang dihasilkan.

1. Peningkatan kualitas proses produksi dan produk tahu bakso melalui manajemen Tabel 1. Hasil Analisis Tahu Bakso

\begin{tabular}{lll}
\hline \multicolumn{1}{c}{ Parameter $^{*}$} & \multicolumn{1}{c}{ Standar** } & \multicolumn{1}{c}{ Aktual } \\
\hline Kadar air & Maks. 70,0\% & $69,6 \%$ \\
Kadar abu & Maks. 3,0\% & $1,91 \%$ \\
Kadar protein & Min. 11,0\% & $25,53 \%$ \\
\%FFA & Maks. 10\% & $0,39 \%$ \\
Angka Lempeng Total & Maks. $1 \times 10^{5}$ koloni/g & $1,3 \times 10^{4} \mathrm{koloni} / \mathrm{g}$ \\
\hline
\end{tabular}

Standar** : Standar-standar tersebut disesuaikan dengan SNI (Standar Nasional Indonesia) 3818-2014 Bakso Kombinasi.

Penetapan pengendalian mutu bahan baku di UKM tahu bakso "EQ" bertujuan untuk menetapkan spesifikasi bahan baku, persyaratan bahan baku yang untuk digunakan sebagai produksi tahu bakso yang lezat, bergizi, dan tanpa bahan pengawet mulai dari tahu, daging, garam, air, bawang putih, MSG, tepung tapioka, merica/lada, dan minyak goreng. Hasil analisa laboratorium bakso "EQ" masih memenuhi standar SNI (Tabel 1).
2. Peningkatan efisiensi proses pengolahan tahu bakso melalui introduksi mesin refrigerator dan alat peningkatan produksi lainnya Mesin refrigerator digunakan untuk menyimpan bahan baku yaitu tahu dan daging untuk bahan isian tahu bakso. Mesin refrigerator ini mempunyai kapasitas 305 liter, sehingga dapat digunakan untuk menyimpan stok daging dan tahu. 
ISSN : 1979-861X

e-ISSN : 2549-1555

\section{Introduksi teknologi variasi bahan pengemas}

Kemasan tahu bakso EQ dapat dilihat pada Gambar 1 yaitu ada kemasan primer dan sekunder. Kemasan primer adalah plastik PP (polypropylene) karakteristik plastik PP lebih kuat dan ringan dengan daya tembus uap yang rendah, ketahanan yang baik terhadap lemak stabil terhadap suhu tinggi dan transparan. Panjang $25 \mathrm{~cm}$, lebar $12 \mathrm{~cm}$, dan tebal 0,8 mm hal ini telah sesuai dengan peraturan perundangundangan No 00-05-55-6497. Kemasan sekunder adalah kemasan yang tidak bensentuhan langsung dengan produknya akan tetapi membungkus produk yang telah dikemas dengan kemasan primer. Di UKM tahu bakso "EQ" kemasan sekunder menggunakan karton dus yang tertera label produk, nama produk, karakteristik produk, alamat UKM, dan nomor telepon pemilik UKM.

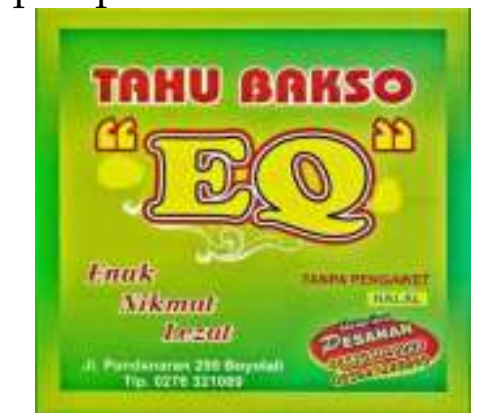

Gambar 1 . Kemasan Tahu Bakso "EQ"

\section{Pengurusan ijin Pangan Industri Rumah Tangga (PIRT) tahu bakso}

Pegurusan ijin Pangan Industri Rumah Tangga (PIRT) sangat diperlukan sebelum memasarkan produk makanan/minuman ke masyarakat. Hal ini diperlukan sebagai izin jaminan usaha makanan / minuman rumahan yang dijual dan beredar di masyarakat memenuhi standar keamanan makanan atau izin edar produk pangan. Belum dimilikinya PIRT pada usaha mitra, mengakibatkan tahu bakso yang dihasilkan oleh industri rumah tangga ini belum dapat dipasarkan ke toko/pusat oleh-oleh yang berada di wilayah Boyolali. Pemasaran saat ini hanya terbatas pada pesanan masyarakat saja. Adapun syarat permohonan pengajuan ijin p-irt adalah mengikuti penyuluhan keamanan pangan, mengisi formulir permohonan izin p-irt, salinan kartu identitas, pas foto $3 \times 4$ dari pemilik usaha, melampirkan rancangan label makanan./minuman, melampirkan denah lokasi usaha dan melampirkan surat dari pemerintah daerah setempat. 
ISSN : 1979-861X

e-ISSN : 2549-1555

\section{Pelatihan manajemen pemasaran dan pembukuan sederhana}

Pemasaran merupakan hal yang sangat penting dalam perusahaan. Sebaik apapun kualitas produk yang dihasilkan, jika tidak dapat memasarkan tidak akan berguna bagi perusahaan. Pemasaran sangat menentukan hidup matinya suatu usaha. Pemasaran tahu bakso yang masih terbatas menjadi kendala perkembangan bisnis mitra. Untuk itu tim pengabdian memberikan pelatihan manajemen pemasaran yang baik agar usaha tahu bakso dapat berkembang yaitu dapat melakukan analisis lingkungan interal dan eksternal usaha tahu bakso, selanjutnya menentukan dan menetapkan kekuatan, kelemahan, peluang dan ancaman yang dihadapi sehingga bisa ditentukan dan ditetapkan arah perusahaan, selanjutnya melakukan formulasi strategi dalam rangka mencapai tujuan perusahaan, selanjutnya dilakukan implementasi strategi yang bisa dilakukan, dan tahap terakhir adalah upaya pengendalian strategi yang dikhususkan pada pemantauan dan evaluasi manajemen strategi dalam rangka untuk memperbaiki dan memastikan bahwa sistem yang diterapkan berjalan dengan mestinya. Strategi pemasaran bersifat berkesinambungan.

Pembukuan merupakan proses pencatatan, pengklasifikasian, dan peringkasan transaksi-transaksi keuangan secara sistematis dan teratur yang disajikan dalam bentuk laporan keuangan, kemudian hasil laporan ini bisa menjadi bahan analisa dan hasil-hasilnya diterjemahkan untuk menjadi dasar keputusan usaha. Pembukuan sangat penting karena keterbatasan manusia dalam menyimpan data informasi keuangan dari usaha yang dijalankan. Pembukuan berfungsi untuk mengukur sejauh mana perkembangan usaha dan kendala yang dapat diatasi. Pembukuan juga berfungsi untuk menentukan arah ke depan apakah perlu dikembangkan atau dikurangi. Pembukuan ini sangat penting untuk dilakukan sebagai evaluasi diri untuk melihat perkembangan usaha dan mengetahui keuntungan atau kerugian yang didapatkan dari usaha yang dijalankan. Pembukuan dapat berfungsi sebagi petunjuk arah atau kompas bagi usaha tahu bakso EQ dalam menjalankan bisnisnya. Dengan diberikan pelatihan pembukuan ini pelaku usaha tahu bakso 
memperoleh pemahaman yaitu mengetahui arus keluar masuk uang di dalam bisnis tahu bakso yang dijalankan, dapat mencegah tercampurnya pengeluaran keuangan pribadi dengan keuangan usaha, mengetahui posisi modal yang digunakan dan modal yang telah kembali, adanya pencatatan / pembukuan dapat mencegah kebangkrutan, dan dapat melakukan analisa/mengambil tindakan yang perlu dari hasil analisa keuangan yang telah dilakukan.

\section{KESIMPULAN DAN SARAN}

\section{A. Kesimpulan}

1. Pelatihan pengetahuan pengusaha bakso "EQ" tentang keamanan bakso "EQ" yang diproduksinya

2. Peralatan untuk peningkatan sanitasi dan higienitas proses produksi bakso "EQ"

\section{Saran}

Mitra dapat melakukan perbaikan aspek sanitasi dengan segera, dari segala aspek agar proses produksi dapat segera mencapai syarat sesuai dengan GMP.

\section{DAFTAR PUSTAKA}

Anonim, 2015. Boyolali Dalam Angka. Badan Pusat Statistik Kabupaten Boyolali.

Hermana. 1985. Kedelai. Pusat Penelitian dan Pengembangan
Tanaman Pangan. Jalan

Merdeka 99, Bogor.

Koswara, S. 2010. Nilai Gizi, Pengawetan dan Pengolahan Tahu. http://www.ebookpangan.com / ARTIKEL/NILAI\%20GIZI,\%2 OPENGOLAHAN\%20DAN\%20 PENGAWETAN\%20TAHU.pdf (diakses pada 29 Januari 2010). Muchtadi, Tien. R. 1997. Teknologi Proses Pengolahan Pangan. Departemen Pendidikan dan Kebudayaan Direktorat Jenderal Pendidikan Tinggi Pusat Antar Universitas. IPB. Bogor.

Radiyati, Tri., et.al. Pengolahan Kedelai. Subang: BPTTG Puslitbang Fisika Terapan LIPI, 1992. Hal. 9 - 14. 